\title{
Biochemical, rheological and hydrophile-lipophile balance (HLB) evaluation of Archachatina marginata (snail) mucin extract for possible nutraceutical and nano biopharmaceutical applications
}

\author{
Mumuni A Momoh ${ }^{1}$, Salome A Chime ${ }^{2}$, Daniel U Ogbodo ${ }^{1}$, Pricillia K Akudike ${ }^{1}$, \\ Stanley U Udochukwu', Emmanuel C Ossai ${ }^{3}$, Franklin C Kenechukwu', \\ Kenneth C Ofokansi ${ }^{1}$, Anthony A Attama ${ }^{1}$ \\ ${ }^{1}$ Drug Delivery Research Unit, Department of Pharmaceutics, ${ }^{2}$ Department of Pharmaceutical Technology and Industrial \\ Pharmacy, Faculty of Pharmaceutical Sciences, ${ }^{3}$ Department of Biochemistry, Faculty of Biological Sciences, University of \\ Nigeria, Nsukka 410001, Nigeria
}

*For correspondence: Email: audu.momoh@unn.edu.ng; Tel: +2348037784357

Sent for review: 18 September 2018

Revised accepted: 15 April 2019

\begin{abstract}
Purpose: To evaluate the rheological, biochemical, hydrophile-lipophile balance (HLB) of Archachatina marginata (snail) mucin extract for possible use as a nutraceutical and nano biopharmaceutical material. Methods: Snail mucin was extracted with acetone and water, lyophilized and the biochemical, proximate and mineral analyses of the extracts were studied using standard methods. The rheological properties of the extracts $(1,2,4$ and $8 \% \mathrm{w} / \mathrm{v})$ and their emulsion-based preparations were evaluated. Other physicochemical properties and HLB values of the preparations were also determined.

Results: Snail mucin extracts contained protein (84\%), fats $(2.91 \%)$ and carbohydrate $(1.2 \%)$ and showed significant nutraceutical composition ( $p<0.05)$. Ash content of 4.21 and $4.12 \%$ was obtained for water and acetone extracts, respectively. Moisture content was $<9 \%$ for both the aqueous and nonaqueous mucin extracts. Potassium, calcium and phosphorus were present in high quantities in the extracts while iron, copper and zinc were in trace amounts (< $4 \%$ ). Mucin dispersions exhibited viscosity in the range of 0.89 to $0.93 \mathrm{cp}$. Water sorption and dry weight were higher in the acetone extract than in the aqueous extract. The HLB values, which ranged from 7 to 15 , were within the acceptable values for material for nanobiopharmaceutical application, except that the acetone extract. Conclusion: Snail mucin exhibits good nutraceutical properties and also possesses good properties that render it a potential excipient for use in the formulation of drug delivery systems.
\end{abstract}

Keywords: Neutraceutical, Biopharmaceutical, Rheology, Mucin, Snail (Archachatina marginata)

This is an Open Access article that uses a fund-ing model which does not charge readers or their institutions for access and distributed under the terms of the Creative Commons Attribution License (http://creativecommons.org/licenses/by/4.0) and the Budapest Open Access Initiative (http://www.budapestopenaccessinitiative.org/read), which permit unrestricted use, distribution, and reproduction in any medium, provided the original work is properly credited.

Tropical Journal of Pharmaceutical Research is indexed by Science Citation Index (SciSearch), Scopus, International Pharmaceutical Abstract, Chemical Abstracts, Embase, Index Copernicus, EBSCO, African Index Medicus, JournalSeek, Journal Citation Reports/Science Edition, Directory of Open Access Journals (DOAJ), African Journal Online, Bioline International, Open-J-Gate and Pharmacy Abstracts

\section{INTRODUCTION}

The use of biomaterial as a carrier in drug delivery systems to combat the barriers posed by drug molecules has attracted a lot of interest and investment [1]. In recent time, research into animal based pharmaceutical excipients is on the increase since most animal products or byeproducts function as good substitute for synthetic products because of their 
biocompatibility, non-toxicity, biodegradability and environmental-friendly nature and as compared to synthetic material [2].

Mucin is the major component of mucus and is the viscous secretion obtained from the goblet cells in the columnar epithelium lining found in all the organs exposed to the external environment. These organs include the gastrointestinal tract, respiratory tract, oculo-rhino-otolaryngeal tracts and the reproductive tract $[3,4]$. Mucin has a protective function such as lubricating some organs for smooth passage of objects; it forms permeable gel layer for the exchange of gases and nutrients with the underlying epithelium and also serves as a barrier to poisonous substances and pathogens [4-7]. Studies carried out on mucin from many organs have revealed that they are macromolecules consisting of subunits joined by inter-chain of disulphide bonds and further stabilized by non-covalent interaction $[8,9]$. The end result of multiple interconnections is an extended and random network, which is responsible for visco-elasticity of the mucus secretions [8]. Mucin from snail has been well researched in the area of drug delivery as well as a carrier. Studies have shown that snail mucin has emulsifying properties [8,9]. However, there is need to carry out extensive research on the physicochemical characteristics of snail mucin extracted using different methods for possible pharmaceutical application.

The hydrophile-lipophile balance (HLB) of a material is of immense importance in formulation design. This study was aimed at exploring the physicochemical properties, rheological characteristics and HLB values of snail mucin extracted using different processing parameters for possible use as nutraceuticals and as excipients in pharmaceutical formulations.

\section{EXPERIMENTAL}

\section{Materials}

Materials used include Span 80 (Sigma Aldrich, Germany), sodium hydroxide, sodium dihydrogen phosphate monohydrate, disodium hydrogen phosphate (Merck, Germany), light paraffin oil, hydrochloric acid, absolute ethanol, sodium chloride, acetone and glutaraldehyde $(\mathrm{BDH}$, England).

\section{Extraction of snail mucin}

Snails were obtained from two different local markets namely; Orba in Enugu state and Otukpa in Benue state, Nigeria.
All the animal experiments of this study was approved by the institutional (University of Nigeria) review board for use of animal subjects under the directorate of research (DOR) (DOR/UNN/17/00012) and were in compliance with the European Community guidelines for the use of experimental animals (Publication No: $86 / 609 / E E C)$ (10). The snails were purchased in bulk in an estivating condition but emerged from their shells and became active after exposure to a humid environment. They were maintained in a humid terrarium and fed on carrots and some established leaves. They were housed within our conferment at International Centre for Ethnomedicinal and Drug Development (InterCEDD) for seven days before the commencement of the study.

\section{Preparation of water-extract of snail mucin}

The mucus secretion of snail was extracted by gently pressing the snail after it has been removed from its shell until no mucus was secreted. The slimes collected from different snails were pooled together in a container and macerated in water for $24 \mathrm{~h}$ at $20^{\circ} \mathrm{C}$ to get a viscous mucus, which was filtered through a muslin cloth to remove unwanted material. The resultant viscous mucus wasthen dried using a lyophilizer (Christ-Alpha 1-2 LD Plus SCIQULP, Germany) at $-40{ }^{\circ} \mathrm{C}$. The extracted mucins were collected and pulverized using an end-runner mill (Pascal Engineering Co Ltd, England). The pulverized mucins were collected and kept in airtight container for further use.

\section{Preparation of acetone-extract of snail mucin}

Chilled acetone was gradually added to the freshly collected mucus and stirred before filtration and drying. The mucin content was then precipitated. The mucin was washed severally with chilled acetone until non-slimy flowing materials were obtained. The resultant precipitate was then exposed to air until all the acetone evaporated and the partially dried residue was lyophilized using a lyophilizer at -40 ${ }^{\circ} \mathrm{C}$ for $72 \mathrm{~h}$. The final dried mucin was collected, pulverized using end-runner mill (Pascal Engineering Co Ltd, England) and stored in an air-tight container. All the extracts were maintained in temperature control system under standard laboratory conditions necessary to maintain the stability of the mucin.

\section{Particle size and size distribution}

The particle size distribution of the snail mucin was studied using dynamic light scattering as described elsewhere $[2,11]$. 


\section{Characterization of dried mucin extract}

\section{Bulk and tapped densities}

The bulk and tapped densities were studied using a $25 \mathrm{ml}$ measuring cylinder. A $15.0 \mathrm{~g}$ quantity of the mucin extract was weighed into the cylinder and the volume occupied by the mucin was recorded as the bulk volume $\left(V_{B}\right)$. The bulk density $\left(\ell_{B}\right)$ was calculated using Eq 1 .

$\ell_{\mathrm{B}}=\frac{M}{W_{B}}$

The cylinder was tapped on a wooden flat surface from a height of five inches at 2 seconds interval until there was no significant $\mathrm{n}$ reduction in volume [11-13] in order to obtain the tapped volume $\left(\mathrm{V}_{T}\right)$ and the tapped density $\left(\ell_{T}\right)$ was calculated using the relation,

$E_{\mathrm{T}}=\frac{M}{V_{T}} \ldots \ldots \ldots$

$\ell_{\mathrm{T}}, \mathrm{M}$ and $\mathrm{V}_{\mathrm{T}}$ are tapped, mass of powder and tapped volume, respectively.

\section{Hausner's ratio and compressibility index}

Hausner's quotient was calculated using Eq 3.

Hausner's quotient $=\frac{f_{T}}{f_{B}}$

$\ell_{\mathrm{T}}$ and $\ell_{\mathrm{B}}$ are tapped and bulk density respectively.

Carr's compressibility index (\%) was determined using,

Canr's index $(\%)=1-\frac{\ell_{B}}{f_{\mathrm{T}}} \times 100$

\section{Dry weight of snail mucin extract}

The moisture content of the various extracts of snail mucin was studied using an established method [14,15]. Briefly, $10 \mathrm{~g}$ each of the snail mucin extracts was accurately weighed into a dried tarred evaporating dish. This was then dried in a Gallenkamp size two oven BS at $75^{\circ} \mathrm{C}$ for $5 \mathrm{~h}$ and the final weight noted. This procedure was repeated three times and the percentage weight was calculated as in Eq 5.

$\%$ moisture content $=\mathrm{W} 1-\mathrm{W} 2 \mathrm{~W} 1 \times 100$ (5)

where $\mathrm{W} 1$ is the initial weight of the mucin and W2 is the final weight of mucin.
Moisture sorption capacity of snail mucin extract

Five gram ( $5 \mathrm{~g})$ quantities of snail mucin extracts (aqueous and acetone extracts) were weighed separately and were spread evenly over the surface of $70 \mathrm{~mm}$ cleaned, tarred and dried Petri dish. Thereafter, the samples were placed in a large desiccator containing distilled water in its reservoir $(\mathrm{RH}=100 \%)$ and stored at room temperature for ten days. Two different humidifiers (A421, Tokyo Japan) connected to a bottle containing $250 \mathrm{~mL}$ of water were used to maintain the humidity of the area. At the end of the ten days period, the samples were weighed and the amount of water absorbed determined using Equation 6.

$W S=B-A / A \times 100$

where WS is the water sorption, $A$ is the initial weight and $B$ is the final weight of mucin after the exposure to water.

Biochemical, proximate and mineral evaluation

The carbohydrate, protein, fixed oil, moisture and ash contents of the mucin extract samples were determined by standard methods of analysis [16]. Also the mineral composition of the mucin extracts for both water and acetone extracts were similarly determined following the established method [16].

\section{Rheological studies}

The measurement of viscosity of the various mucin extracts was done with viscometer (Digital Rotary Viscometer, model NDJ-SS06001497, China). Briefly, four different batches of preparation consisting of $2,4,6$, and $8 \% \mathrm{w} / \mathrm{v}$ dispersions of the various extracts (aqueous and acetone extracts) of snail mucin were separately prepared in water and rotated for $2 \mathrm{~min}$ at different speeds $(6,12,30$ to $60 \mathrm{rpm})$ using spindles or rotor numbers 1 and 2. Triplicate readings were determined. The $\mathrm{pH}$ values of the various dispersions were similarly determined using a calibrated $\mathrm{pH}$ meter (Horiba digital $\mathrm{pH}$ meter, Japan). The $\mathrm{pH}$ was evaluated periodically to ascertain the level of changes in the preparation overtime as an indicator of stability of the dispersions.

\section{Preparation of emulsion based on snail mucin extract}

Snail emulsions consisting of $0.05 \%(w / w)$ mucin and $30 \%$ liquid paraffin oil phase, were prepared 
by simple mixing and further homogenized using a homogeniser. Then, distilled water was gradually added into the mixture. The resulting coarse emulsion was homogenized by using Ultra-turrax $^{\circledR}$ (IKA, Germany) at 10,000 rpm for $10 \mathrm{~min}$. The same procedure was used for the other batches of the preparation. These formulations were subjected to various evaluations as stated below.

\section{Physical examination of emulsion}

Changes in the physical appearance of the preparations and odor formation were monitored throughout the study.

\section{Measurement of pH of emulsions}

The $\mathrm{pH}$ of each of the emulsions was measured using a $\mathrm{pH}$ meter (Horiba digital $\mathrm{pH}$ meter, Japan). In brief, a $20 \mathrm{ml}$ of each preparation was added into 25-ml tubes, covered and stored in refrigerator at $25{ }^{\circ} \mathrm{C}$. At predetermined time intervals, the $\mathrm{pH}$ values of the samples were measured and recorded. All the measurements were carried out in triplicates and the average readings were recorded.

\section{Measurement of sedimentation rate}

The sedimentation rate of the preparations was also evaluated. Briefly, a $50 \mathrm{ml}$ portion of each of the preparation was added into a centrifuge tube and centrifuged for $20 \mathrm{~min}$ at a speed of 12000 $\mathrm{rpm}$ at $10^{\circ} \mathrm{C}$. The separation of clear liquid was measured and the percentage of the sedimentation volume, F (\%), was calculated with reference to the initial volume $\left(\mathrm{V}_{\mathrm{o}}\right)$ and the sediment volume $\left(\mathrm{V}_{\mathrm{u}}\right)$ of the preparation using $\mathrm{Eq}$ 7.

$F=100 \times V_{U} / V_{0} \ldots \ldots(7)$

\section{Determination of HLB value}

The HLB of the snail mucin was determined according to the method described by Aveyard et al. [17]. Series of emulsions were prepared with varying ratios of Tween 80 and the mucin powder. The percentage of the total emulsifying agent (mucin and Tween 80 ) was fixed at $1 \%$ in all cases. The first series of emulsions contain emulsifier's blends of ratios ranging from 1:9 to 4:6 respectively. The (HLB) of the mucin was then calculated using the equation below.

$\mathrm{HLB}=\mathrm{R}-\frac{(\text { HxS })}{\mathrm{N}}$ where $R$ is "required HLB" of liquid paraffin, $H$ is HLB of Tween 80 used, $S$ is the percent of Tween 80 expressed as a decimal fraction and $\mathrm{N}$ is the percent of mucin powder expressed as a decimal fraction. This method was repeated for the two different extracts of mucin and the HLB of each was calculated and compared to the established values for good emulsifying agents for pharmaceutical applications.

\section{RESULTS}

The results of the biochemical and proximate analysis of snail mucin obtained by acetone and water extraction respectively are shown in Table 1. The results revealed that snail mucin extracted with water mucin had $84 \%$ protein (water extract), $2.91 \%$ fats and $1.2 \%$ carbohydrate. The acetone extracts gave higher extracts of the entire nutrient, except for protein which had higher values for the water extract of mucin than acetone. However, these values were not significant $(p<0.05)$. The ash content of about $4.21 \%$ was obtained for mucin extracted with acetone, while the mucin extracted with water had ash content of $4.12 \%$. The moisture contents were $<9 \%$ for both the aqueous and nonaqueous mucin extracts.

Table 1: Biochemical proximate and mineral profile of snail mucin extracts

\begin{tabular}{lcc} 
Parameter & $\begin{array}{c}\text { Acetone } \\
\text { extract }\end{array}$ & $\begin{array}{c}\text { Water extract } \\
\text { (lyophilized) }\end{array}$ \\
\hline Carbohydrate (\%) & 1.20 & 0.90 \\
Protein (\%) & 71.00 & 84.00 \\
Lipid (Fixed oil) (\%) & 2.91 & 2.61 \\
Ash value (\%) & 4.21 & 4.12 \\
Moisture (\%) & 8.50 & 7.50 \\
Iron (\%) & 3.40 & 3.39 \\
Calcium (\%) & 321.00 & 321.00 \\
Potassium (\%) & 296.00 & 290.00 \\
Copper (\%) & 1.20 & 1.20 \\
Zinc (\%) & 3.30 & 3.10 \\
Phosphorus (\%) & 216.00 & 206.00 \\
\hline
\end{tabular}

Note: All percentages were calculated with reference to $20 \mathrm{~g}$ of mucin.

The results of the mineral constituents of snail mucin extracts are also shown in Table 1 and it showed that snail mucin is rich in the following minerals: potassium, calcium and phosphorus. Iron, copper and zinc were found in small quantities (< $4 \%$ ).

\section{Physical properties and $\mathrm{pH}$ change}

The changes in the physical parameters of the various extracts of the snail mucin (acetone and aqueous extracts) are shown in Table 2. The percentage mucin yield of water extract was 
$68.20 \% \mathrm{w} / \mathrm{w}$ while the percentage mucin yield of acetone extract was $35.50 \%$ w/w. Hence, water gave significantly higher mucin yield than acetone $(p<0.05)$.

The colour (Table 2) of the aqueous mucin extract was light brown and retained less meat characteristics odour, with free-flowing particles while that of acetone extract was dark brown in colour and no obvious odour observed, however, it shows a much more free-flowing particles than the aqueous extract.

The results of the $\mathrm{pH}$ showed that a range of 7.1 to 9.2 were obtained for mucin extracted with acetone over time, while the aqueous extract showed a $\mathrm{pH}$ range of 9.7 to 9.9 from $24 \mathrm{~h}$ to 4 weeks. The results revealed no significant change in $\mathrm{pH}$ over time.

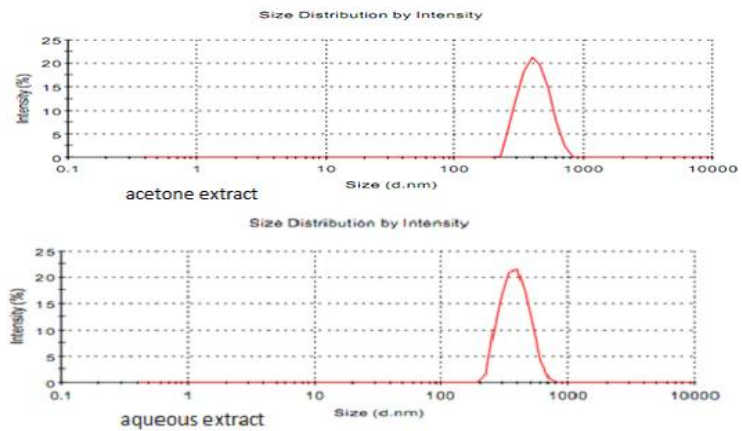

Figure 1: Particle size distribution of mucin extracts

The particle size distribution of various mucin extracts as obtained by dynamic light scattering (DLS) is presented in Figure 1. The particle sizes were in the nanometer range and were not significantly different $(p>0.005)$.

The angles of repose $\left(^{\circ}\right)$, Carr's index and Hausner's ratio of acetone extract are $26.1^{\circ}, 27.1$ $\%$ and 1.32 respectively, while the water extract

had angle of repose of $24.1^{\circ}$, Carr's index of $14.11 \%$ and Hausner's quotient of 1.21, respectively.

The results of moisture sorption showed that the water extract of the mucin had more moisture content $(14.0 \% \mathrm{w} / \mathrm{w})$ than the acetone extract $(10.0 \% \mathrm{w} / \mathrm{w})$. The gain in the moisture content or water sorption of the extracts after exposure to relative humidity was in the order: acetone extract $(8.3 \% \mathrm{w} / \mathrm{w})>$ water extract $(5.6 \% \mathrm{w} / \mathrm{w})$, but this increase was not significant $(p<0.05)$.

The formulations exhibited slow sedimentation while redispersibility was readily achieved. They were white in colour and odourless. The various ratios of Tween 80 to mucin in the emulsion and paraffin oil were assessed and all the formulations were emulsions stable as shown in Table 3. HLB range of 5 - 15 were also obtained as shown in Table 3.

Table 2: Physicochemical and organoleptic properties of mucin based-emulsion

\begin{tabular}{|c|c|c|}
\hline Sample* & $\mathrm{pH}$ at $24 \mathrm{~h}$ & $\begin{array}{c}\text { pH at } 4 \\
\text { weeks }\end{array}$ \\
\hline Acet 1 & 7.1 & 7.1 \\
\hline Acet 2 & 7.2 & 7.3 \\
\hline Acet 3 & 7.5 & 7.5 \\
\hline Acet 4 & 8.0 & 8.0 \\
\hline Acet 5 & 8.5 & 8.5 \\
\hline Acet 6 & 9.2 & 9.2 \\
\hline Aquo 1 & 9.7 & 9.7 \\
\hline Aquo $_{2}$ & 9.8 & 9.9 \\
\hline Aquo $_{3}$ & 9.8 & 9.9 \\
\hline Aquo $_{4}$ & 9.7 & 9.7 \\
\hline Aquo 5 & 9.8 & 9.9 \\
\hline Aquo 6 & 9.8 & 9.9 \\
\hline
\end{tabular}

Table 3: Hydrophile-lipophile balance (HLB) of extracts of mucin-based emulsion

\begin{tabular}{|c|c|c|c|c|c|}
\hline Samples* & Mucin:Tween 80 & $\begin{array}{c}\text { Height of } \\
\text { creaming }(\mathrm{cm})\end{array}$ & $\begin{array}{c}\text { Volume of } \\
\text { creaming (ml) }\end{array}$ & $\begin{array}{c}\text { Creaming } \\
(\%)\end{array}$ & HLB value \\
\hline Acet $_{1}$ & $1: 9$ & 0.1 & 1.45 & 1.45 & 15.0 \\
\hline Acet 2 & $2: 8$ & 0.1 & 1.45 & 1.45 & 0.0 \\
\hline Acet 3 & $3: 7$ & 0.3 & 4.35 & 4.35 & 5.0 \\
\hline Acet 4 & $4: 6$ & 0.4 & 5.80 & 5.80 & 7.5 \\
\hline Acet 5 & $5: 5$ & 0.2 & 2.89 & 2.89 & 9.0 \\
\hline Acet 6 & $6: 4$ & 0.3 & 4.35 & 4.35 & 10.0 \\
\hline Aquo $_{1}$ & $1: 9$ & 0.1 & 1.45 & 1.45 & 10.7 \\
\hline Aquo $_{2}$ & $2: 8$ & 0.2 & 2.89 & 2.89 & 11.3 \\
\hline Aquo $_{3}$ & $3: 7$ & 0.1 & 1.45 & 1.45 & 11.7 \\
\hline Aquo $_{4}$ & $4: 6$ & 0.2 & 1.45 & 1.45 & 9.7 \\
\hline Aquo $_{5}$ & $5: 5$ & 0.2 & 2.82 & 2.82 & 10.3 \\
\hline Aquo $_{6}$ & $4: 6$ & 0.3 & 1.45 & 1.45 & 11.7 \\
\hline
\end{tabular}

Note: Initial vol. of emulsion: $6.9 \mathrm{~cm}=100 \mathrm{~cm} ;{ }^{*}$ Acet $=$ mucin extracted with acetone; Aquo = mucin extracted with water 
Table 4: Rheological properties of mucin-emulsion

\begin{tabular}{|c|c|c|c|c|}
\hline Samples* & Time of flow (s) & Density $(\mathrm{g} / \mathrm{cm} 3)$ & $\begin{array}{l}\text { Relative } \\
\text { density }\end{array}$ & Viscosity (cP) \\
\hline Acet 1 & 60 & 0.65 & 0.65 & 0.89 \\
\hline Acet 2 & 56 & 0.70 & 0.70 & 0.90 \\
\hline Acet 3 & 50 & 0.78 & 0.78 & 0.89 \\
\hline Acet 4 & 52 & 0.75 & 0.75 & 0.89 \\
\hline Acet 5 & 50 & 0.78 & 0.78 & 0.93 \\
\hline Acet 6 & 49 & 0.80 & 0.80 & 0.90 \\
\hline Aquo $_{1}$ & 45 & 0.87 & 0.87 & 0.89 \\
\hline Aquo $_{2}$ & 44 & 0.89 & 0.89 & 0.89 \\
\hline Aquo $_{3}$ & 43 & 0.91 & 0.91 & 0.89 \\
\hline Aquo $_{4}$ & 52 & 0.75 & 0.75 & 0.89 \\
\hline Aquo 5 & 50 & 0.65 & 0.65 & 0.93 \\
\hline Aquo $_{6}$ & 49 & 0.80 & 0.80 & 0.90 \\
\hline
\end{tabular}

Note: Initial vol. of emulsion: $6.9 \mathrm{~cm}=100 \mathrm{~cm}$; Acet = mucin extracted with acetone; Aquo = mucin extracted with water

The viscosity of the mucin dispersions vary as the concentration changes from 2, 4, 6 and 8 $\%$ w/v (Table 4). Highest and lowest viscosity of $113.5 \mathrm{cp}$ and $18.0 \mathrm{cp}$ with corresponding shear of 11.2 and 3.2 were obtained for 2 and $8 \%$ respectively, at rate of $60 \mathrm{rpm}$ for the acetone extract. However, the water extract gave highest and lowest viscosity values $(93.2 \mathrm{cP}$ and $1.5 \mathrm{cP}$, respectively) with a corresponding shear of 13.2 and 1.1 at $60 \mathrm{rpm}$ respectively.

\section{DISCUSSION}

The results of the biochemical and proximate analysis of snail mucin confirmed the fact that snail mucin have some nutraceutical application in addition to some other numerous functions in the body. The results revealed that the moisture content were generally low and would not be able to encourage microbial growth.

Mucin was found to be rich in minerals and this is particularly important for patients deficient in these minerals. Calcium is particularly important for bone and teeth development; therefore, use of snail mucin in pediatric and geriatric dosage forms not only serves to improve absorption, but also contributes as a food supplement, otherwise referred to as 'nutraceuticals' in this work. The presence of about $3.3 \%$ of iron in snail mucin revealed the fact that it could also enhance the production of red blood cells and hence improve the packed cell volume (PCV). These results showed that acetone and water could be used as extracting solvents in the preparation of snail mucin. Also, aqueous extract (except for protein) had values for the minerals and nutrients insignificantly below those prepared with acetone $(p<0.05)$.

The results of the percentage yield of mucin showed that water extract had a better yield than acetone extract. The reason for the variation in the yield was as a result of the activities of acetone on the removal of fat and some other soluble material in the mucin, such that there would be an obvious reduction in the recovery weight. Acetone removed some fat in mucin and other soluble materials and that explains the lower yield obtained. Whereas the water extract was high as the non-water soluble components were still very much retained in the recovery material.

The organoleptic properties of the mucin extracts exhibited good stability and aesthetics values as exemplified by the odourless, good sedimentation, redispersibility and easy pourability (Table 2). The results of the $\mathrm{pH}$ of the mucin extracts as shown in Table 2 indicate that the change in the $\mathrm{pH}$ of the formulations was not significant $(p<0.05)$. This result is in agreement with the specification for an ideal emulsion $[18,19]$. According to an earlier author, stable and well prepared emulsion should exhibit the rheological properties of plasticity, and easy redispersibility and good pourability [20].

The particle size range was predominated in nanometer range and was almost the same in both extracts, with insignificant difference $(p>$ 0.005). However, the particles sizes showed unimodal size distribution however, the aqueous extracts showed a lesser sharp peak than the acetone extract. The result of the micromeritics properties indicates that the extract showed good flowability and could be used as excipient in pharmaceutical drug delivery.

The results of the emulsion stability shown in Tables 2 and 3 attest to the fact that the formulations were stable, and easily redispersible. The least creaming level was found to be mucin-oil ratio of $1: 9$, and the HLB values of all the preparations except batch (3:7) of the acetone extract are within the acceptable 
range. The HLB values (Table 3 ) are within the acceptable range of $7-16$ which are best fitted for oil/water emulsifying agents [21,22]. Both extracts showed good emulsifying properties.

The viscosity of the dispersions increases with increase in concentration of mucin and there was a significant difference between the least and highest concentrations. Spindles or rotor 1 and 2 were used for the dispersion 2 and $4 \% \mathrm{w} / \mathrm{v}$ and spindle 3 and 4 were used for the 6 and $8 \% \mathrm{w} / \mathrm{v}$ dispersion. The shear stress changed as the concentration changed too and the order was concentration dependent. This indicates that there is a direct relationship between the concentration and the viscosity of the dispersion.

\section{CONCLUSION}

Mucin extract exhibited good rheological properties that could be used in the formulation of stable emulsions. Combination of various mucin extracts with Tween 80 yielded emulsions with very high stability. The HLB values of the emulsion were within the acceptable range for material that could serve as an emulsifier as well as suspending agent. The various mucin extracts demonstrated good nutraceutical properties and possess great potential to be used as nano drug carrier for oral delivery.

\section{DECLARATIONS}

\section{Acknowledgement}

The work was done with the financial support from Tertiary Education Trust Fund (TETFund) under grant no. TETFUND/DESS/NRF/STI/13.

\section{Conflict of interest}

No conflict of interest is associated with this work.

\section{Contribution of authors}

We declare that this work was done by the authors named in this article and all liabilities pertaining to claims relating to the content of this article will be borne by the authors.

\section{Open Access}

This is an Open Access article that uses a funding model which does not charge readers or their institutions for access and distributed under the terms of the Creative Commons Attribution License (http://creativecommons.org/licenses/by/ 4.0) and the Budapest Open Access Initiative (http://www.budapestopenaccessinitiative.org/rea d), which permit unrestricted use, distribution, and reproduction in any medium, provided the original work is properly credited.

\section{REFERENCES}

1. Westesen K, Siekmann B. Solid lipid nanoparticles of bioactive agent and method for the manufacture and use thereof. United States Patent 1998; 5785, 976.

2. Attama AA, Okafor CE, Builders PF, Okorie $O$. Formulation and in vitro evaluation of a PEGylated microscopic lipospheres delivery system for ceftriaxone sodium. Drug Deliv 2009; 16: 448-616.

3. Rama B, Bradley ST. Mucin structure, aggregation, physiological functions and biomedical applications. Cur Opn Coll Interf Sci 2006; 11: 164-170.

4. Felipe M, Fenton TM, Forss C, Smedley C, Anu G, MacDonald AS, Thornton DJ, Travis MA. Intestinal mucin activates human dendritic cells and IL-8 production in a glycan-specific manner. $J$ Biol Chem 2018; Doi: 10.1074/jbc.M117.789305.

5. Allen A. Structure and function of gastrointestinal mucus. In: Johnson L, editor. Physiology of the gastroenterology tract, 1st edn. New York, NY' Raven Press; 1981; pp 617-639.

6. Neutra M, Forstner J. Gastrointestinal mucus: synthesis, secretion, and function. In: Johnson $L$, editor. Physiology of the gastrointestinal tract, 2nd edn. New York, NY' Raven Press; 1987; pp 975-1009.

7. Bell S, Xu G, Khatri I, Wang R, Rahman S, Forstner J. Nlinked oligosaccharides play a role in disulphidedependent dimerization of intestinal mucin Muc 2. Biochem J 2003; 373(3): 893-900.

8. Forstner JFJ, Abbal I, Qureshi R, Kells DIC, Forstner GG. The role of disulphide bonds in human intestinal mucin. Biochem J 1979; 181: 725-732.

9. Caron G, Visentin S, Pontremoli C, Ermondi G. Profile of the intermolecular forces governing the interaction of drugs with mucin. Int J Pharm 2015; 488(1-2): 67-69.

10. Onyishi VI, Chime SA, Adibe CV. Formulation of pyridoxine hydrochloride sustained release capsules: Effect of propylene glycol co-solvent on the in vitro release. Afr J Pharm Pharmacol 2013; 7(15): 809-815.

11. European Community Council Directive on the ethics of experiments involving laboratory animals (Publication No: 86/609/EEC), November 24, 1986.

12. Chime SA, Attama AA, Agubata CO, Ogbonna JD, Onunkwo GC. Micromeritic and antinociceptive properties of lyophilized indomethacin-loaded SLMS based on solidified reverse micellar solutions. J Pharm Res 2012; 5(6): 3410-3416.

13. Onyishi IV, Chime SA, Ugwu JC. Evaluation of binder and disintegrant properties of starch derived from Xanthosoma sagittifolium in metronidazole tablets. Afr $\mathrm{J}$ Biotech 2013; 12(20): 3064-3070.

Trop J Pharm Res, May 2019; 18(5): 933 
14. Malviya R. Extraction and characterization of selected mucilage as pharmaceutical excipients. Polymer in Medicine 2011; 41 (3): 39-44.

15. Ohwoauworhua FO, Kunle OO, Ofoefule SI. Extraction and characterization of microcrystalline cellulose derived from luffa cylindrical plant. Afri J Pharma Res Dev 2004 ;(3): 1-6.

16. Association of Official Analytical Chemists (AOAC). Official method of analysis, 15th edition. Washington DC, 1990; pp 220-224.

17. Graffin WC. Surfactants as emulsifying agents. J Soc Cosmet Chem 1954; 5: 249-250.

18. Aveyard R, Binks BP, Clint JH. Emulsions stabilised solely by colloidal particles, Adv. Colloid Interface Sci 2003; 100-102: 503-546.
19. Beg S, Swain S, Singh HP, Patra CN, Rao, MB. Development, optimization, and characterization of solid self-nanoemulsifying drug delivery systems of valsartan using porous carriers. AAPS Pharm SciTech 2012; 13 : 1416-1427.

20. Binks BP, Tyowua AT. Oil-in-oil emulsions stabilised solely by solid particles, Soft Matter 2016; 12: 876-887.

21. Abarca RL, Rodriguez FJ, Guarda A, Galotto M.J, Bruna JE. Characterization of beta-cyclodextrin inclusion complexes containing an essential oil component, Food Chem 2016; 196: 968-975.

22. Adikwu MU, Udeala OK, Ohiri FC. Evaluation of prosopis gum in tabletting; binding properties in granules and tablets. Sub-Trop Pharm Sci 1992; 1(2): 159-163. 